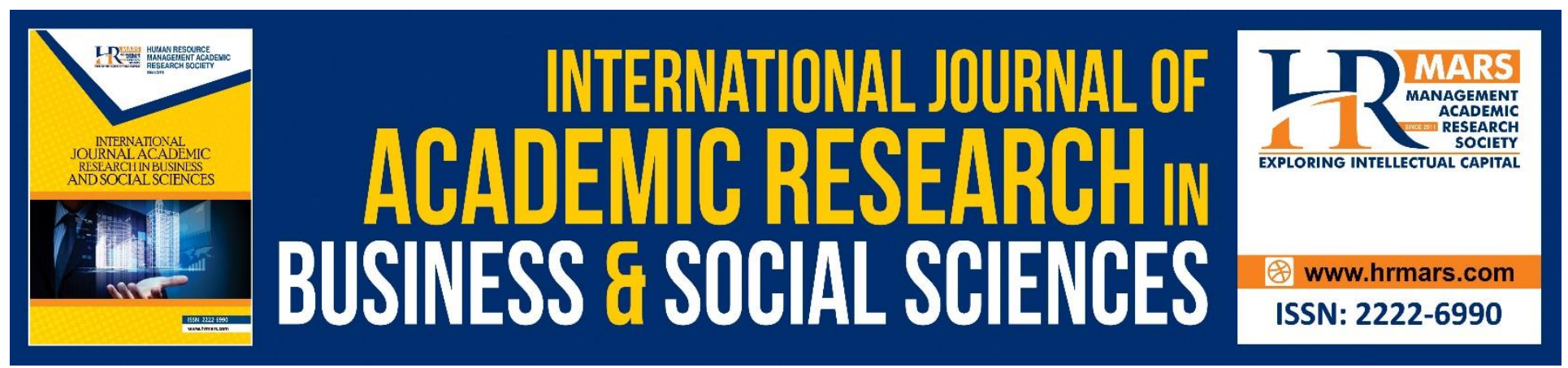

\title{
Human Capital Strategy for Support Staff in Malaysia Public University
}

\begin{abstract}
Nurul Fadly Habidin, Sharon Ong Yong Yee, Nursyazwani Mohd Fuzi \& Ummu Aiman Muhamad
\end{abstract}

To Link this Article: http://dx.doi.org/10.6007/IJARBSS/v8-i10/5307

DOI: $10.6007 /$ IJARBSS/v8-i10/5307

Received: 17 Sept 2018, Revised: 22 Oct 2018, Accepted: 01 Nov 2018

Published Online: 04 Nov 2018

In-Text Citation: (Habidin, Yee, Fuzi, \& Muhamad, 2018)

To Cite this Article: Habidin, N. F., Yee, S. O. Y., Fuzi, N. M., \& Muhamad, U. A. (2018). Human Capital Strategy for Support Staff in Malaysia Public University. International Journal of Academic Research in Business and Social Sciences, 8(10), 1397-1403.

Copyright: (C) 2018 The Author(s)

Published by Human Resource Management Academic Research Society (www.hrmars.com)

This article is published under the Creative Commons Attribution (CC BY 4.0) license. Anyone may reproduce, distribute, translate and create derivative works of this article (for both commercial and non-commercial purposes), subject to full attribution to the original publication and authors. The full terms of this license may be seen

at: $\underline{\text { http://creativecommons.org/licences/by/4.0/legalcode }}$

Vol. 8, No. 10, 2018, Pg. 1397 - 1403

http://hrmars.com/index.php/pages/detail/IJARBSS

JOURNAL HOMEPAGE

Full Terms \& Conditions of access and use can be found at http://hrmars.com/index.php/pages/detail/publication-ethics 


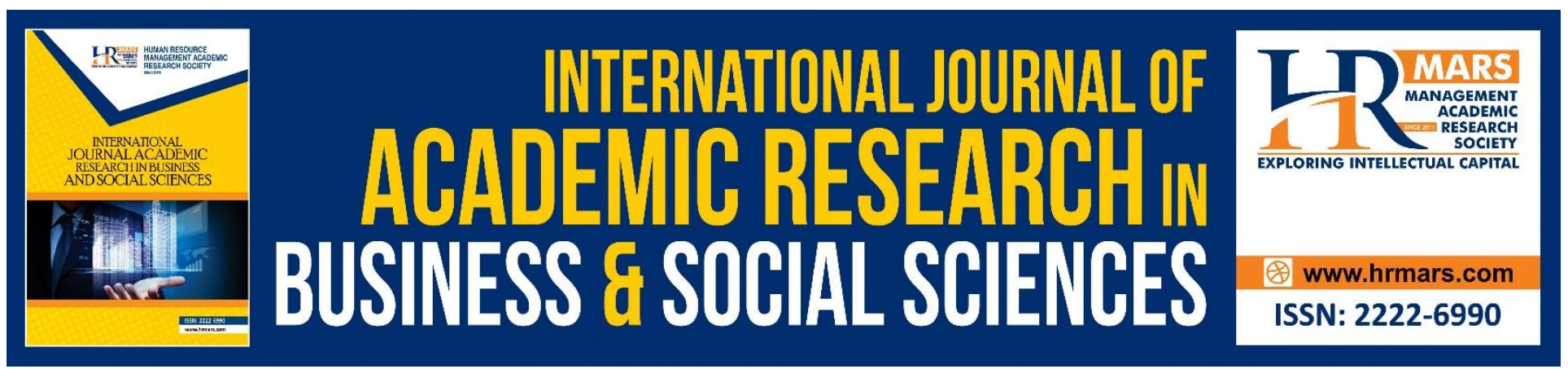

\title{
Human Capital Strategy for Support Staff in Malaysia Public University
}

\section{${ }^{* 1}$ Nurul Fadly Habidin, ${ }^{2}$ Sharon Ong Yong Yee, ${ }^{3}$ Nursyazwani Mohd Fuzi \& ${ }^{4}$ Ummu Aiman Muhamad}

\#1, 2, Department of Management and Leadership, Faculty of Management and Economics, Universiti Pendidikan Sultan Idris, 35900 Tanjung Malim, Perak, Malaysia

${ }^{3}$ Department of Accounting and Finance, Faculty of Management and Economics,

Universiti Pendidikan Sultan Idris, 35900 Tanjung Malim, Perak, Malaysia

${ }^{4}$ Faculty of Education and Human Development, Universiti Pendidikan Sultan Idris, 35900 Tanjung Malim, Perak, Malaysia

\begin{abstract}
Employee reduction issues are increasing especially in universities. Therefore, to overcome the problems faced in reducing the workforce at universities. The study aims to identify employees' experience of employee reduction during university services, identifying the experience in the reduction of the employee may affect the emotional state of the employees at the university and determine the employee reduction strategy affects the retention performance of employees at the university. The quantitative method will be used in this study to obtain the findings. This study is expected to contribute to the employee reduction strategy that affects the performance of retention of employees at the university and helps to improve the retention performance of public university's support employees.
\end{abstract}

Keywords: Human Capital Strategy, Employee Reduction, Employee retention performance, Public university, Malaysia

\section{Introduction}

Employee reductions have become an advantage of competitiveness and improve organizational performance, reductions have existed for a while. However, its impact on workers' or organizational performance has brought mixed reactions in both developed and developing countries. According to Cascio (2002), the reduction refers to contemporary development in relation to the reduction of fixed employment driven by efforts to improve operational efficiencies. In fact, how to narrow down effectively is not only important for organizations that are experiencing difficulties, but also as a 
proactive strategy for healthy organizations.

In the Kinanga and Cheruiyot (2015) study, researchers are reviewing the reduction and effect of organizational performance and academic research and suggest levels of work and reduction in the employee directly from the demand for the product or service. Carriger (2017) stated that employee reduction is an intentional decision by the organization to reduce labor. This process is implemented with the ultimate goal of improving performance within the organization. This is because reductions as an option set by the organization to reduce the next workforce will improve the organization's performance. Similarly, Bear and Hwang (2017) state that reductions are processes where organizations reduce the workforce and create excessive assets with the goal of achieving cost reduction and improving efficiency.

Additionally, the reduction of workers is considered as one of the preferred routes to reduce costs and improve organizational performance as a cost reduction measure. This is because termination of service is a different experience for each individual. It also relates to personal experience in managing service termination activities when making decisions, execution and processes in reducing employees in the organization. Therefore, in addressing the problems faced in reducing the workforce in the organization, especially in universities, this study aims to achieve the objective of identifying employee experience during university service, identifying the experience in the reduction of the employee can affect the emotional state employees at the university and determine the employee reduction strategy affects the retention performance of employees at the university.

\section{Literature Review \\ Reduction of Employee in Public University}

Employee reduction is an issue that is being raised in recent years. The world economic crisis is a major cause of the decline of workers worldwide especially in Malaysia. It is indeed an unwanted phenomenon by many parties and can not be overcome within a short period of time. The crisis that has hit this huge impact, especially in the Public University. To address issues in the reduction of employees in the university more attentively during the organizational restructuring process, this study can help resolve issues that are increasing in connection with the reduction of employees in the university. In the reduction of the worker, the process of termination of service can lead to emotionally in the physical and emotional stress of an individual. In addition, the problem in this study is to identify the implementation of six strategies to realize the workforce reduction initiatives in terms of right-sizing, duplication duplication reviews, alignment of realignment services, services that can be handed over ( outsourcing), business process reengineering and review of revision schemes affect the retention of employees at the university.

According to the study of Yaacob and Yusoff (2010), workers are a very important asset to an organization to manage operations, due to the world economic crisis that has hit many workers who have been laid off. However, the reduction of workers employed by the employer must follow the guidelines laid down in order to prevent the oppression of workers and retrenched workers who are 
entitled to their entitlement. To address this problem, all parties should work together and partner in order to address this issue more efficiently and effectively so that it does not continue to rampant.

The study also found that the reduction of workers is an injustice to workers, especially in universities. This is because the employer arbitrarily dismissed the employee irrespective of the emotion that would be disturbed by the employee with the economic downturn. This is because it happens suddenly and it burdens employees to get other jobs in no time. This situation is more burdensome for low-income workers to bear the family. Additionally, the reduction of this worker has a profound effect on the life of the retrenched worker. Therefore, the employer should provide an early notice so that the worker will be able to stop being able to get another job before being laid off.

In addition, to ensure that the reduction of workers is not done arbitrarily, employers need to have a strong reason to do so. Employers can also increase their efficiency in organizational management to manage administration, especially in universities. This is supported by Chhinzer and Currie (2014) that the reduction of workers should be emphasized to minimize emotional disturbance of an individual. Therefore, this study is able to determine the employee reduction strategies affecting the retention performance of employees, especially in universities. Based on the issues that need to be addressed in this study, the employer must first understand the impact that the decision to reduce the employee. As a result of the gap in literature, the organization may not be aware of the actual worker experience and emotional impact required. Therefore, this effect can achieve the objective of study related to the reduction of workers, especially in the unversity.

\section{Human Capital Strategy}

Employee reduction strategies affect the retention performance of employees at universities. The strategic approach to employee reduction refers to the form of best practices that contribute to the achievement of organizational goals and strategies (Philip \& Ting, 2013), and in this case refer to the method used to achieve the reduction of manpower in publics university. Boon, Eckardt, Lepak \& Boselie (2018) refer human capital strategy as strategy that focus on human capital resources, specificity of human capital, human capital resource emergence and dispersion of human capital. Researchers are viewing unit-level human capital resources as a portfolio of individual level human assets (Nyberg et al., 2014). In this study, Human Capital strategy can be carried out with the implementation of six strategies for realizing Public Service initiatives, Right-sizing controls, duplication reviews, realignment functional services, outsourcing), business process reengineering and review of revision schemes (Vakola, 1999; Vatanartıran, 2015; Jones, 2018). This is an effort that is in line with the approach towards the economy and the Government's desire to produce knowledgeable workers. This strategic approach takes into account all the factors that contribute to the achievement of organizational goals. Employee performance evaluation is one way that allows an individual to leave the organization. This is because the employee's performance evaluation is the formal process of the organization being used towards providing recognition and encouraging the expansion of employees or employees. To be effective, the process must support the organization in maintaining high potential employees. Effective staff reduction strategies are a work of retention of employees who need to be pressured by organizations, especially in universities. With this study, it 
INTERNATIONAL JOURNAL OF ACADEMIC RESEARCH IN BUSINESS AND SOCIAL SCIENCES

Vol. 8, No. 10, Oct. 2018, E-ISSN: 2222-6990 ㄷ 2018 HRMARS

can improve the employee reduction strategy affecting the employee retention performance of the university.

\section{Objective of the Study}

The objectives of this study are:

1. Identify the level of competence of support staff according to job descriptions.

2. Identify effective and efficient support staff in carrying out task load.

3. Identify the effectiveness in the deployment of support staff in accordance with the role and responsibility of University.

4. Generate analytical path of human capital success framework of support staff.

5. Identifying experiences in the reduction of workers can affect the emotional state of the employees at the university.

6. Identifying employee reduction strategies affects the employees retention performance AT Public University.

7. Identify the implementation of six strategies to realize employee reduction initiatives in terms of right-sizing, duplication reviews, realignment service outsourcing, outsourcing services, reengineering of work processes (business process reengineering) and review of service schemes (revisions) affect the retention performance of university employees.

\section{Method}

This study is a quantitative study. Data is collected from each employee from the sample size in which each analysis is made up of one individual. Respondents are comprised of administrative staff at the university. This facilitates the interview process and the distribution of questionnaires to be done in collecting data. Samples selected random sampling randomized so that management and nonmanagement groups can represent accordingly. The research list represents all administrative staff. The purpose of using strata sampling is to ensure that staff from the administrative group are involved in this study. The data were then analyzed using descriptive analysis. Statistical data will be analyzed using the Statistical Package For Social Science (SPSS) Version 22.0 software to interpret data results and has been widely used by most researchers. In addition, reliability is analyzed using Alfa Cronbach. This study also uses an exploratory factor analysis in determining each dimension in this study. The study will use five Likert Scales from 1 (Strongly Disagree) to 5 (Strongly agree) consisting of employee experience of employee reduction during university service, experience in the reduction of the employee may affect the emotional state of the employees at the university and determine the employee reduction strategy impact on employee retention performance at universities. 
INTERNATIONAL JOURNAL OF ACADEMIC RESEARCH IN BUSINESS AND SOCIAL SCIENCES

Vol. 8, No. 10, Oct. 2018, E-ISSN: 2222-6990 ㄷ 2018 HRMARS

\section{Findings}

The framework for Human Capital Strategy for Support Staff in Malaysia Public University:

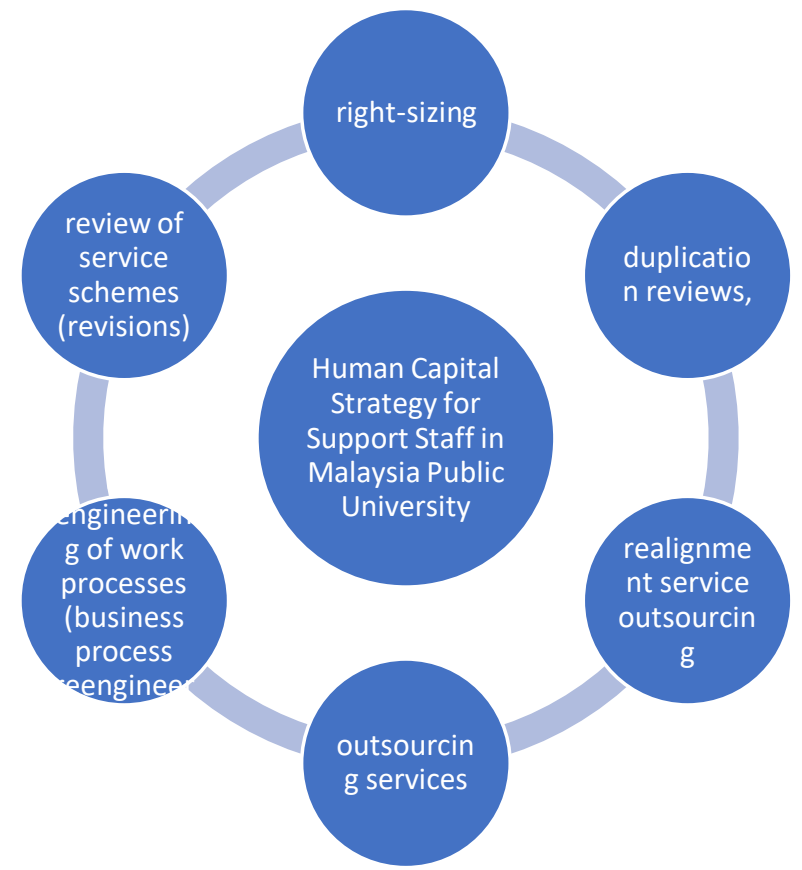

Figure 1.0 The framework for Human Capital Strategy for Support Staff in Malaysia Public University

\section{Conclusion}

As a conclusion, the organization should identify the employee's experience of employee reduction during university services and identify experience in the reduction of the employee may affect the emotional state of the employee at the university. Additionally, this study was able to determine the employee reduction strategy that affected the retention performance of the university's employees. This is because staff reductions need to be emphasized especially at universities to improve the retention performance of employees. Therefore, employees are a very important asset to an organization to carry out operations. By conducting this study, it helps the organization to improve the retention performance of employees at universities by implementing employee reduction strategies comprising size controls, cross-agency functional overlap reviews, key functional service alignment, manageable services, work process engineering and review reviews service scheme.

\section{Acknowledgement}

The researchers would like to acknowledge Research Management and Innovation Centre (RMIC), Universiti Pendidikan Sultan Idris (UPSI) for Research University Grant (RUG).

\section{Corresponding Author}

Nurul Fadly Habidin

Department of Management and Leadership, Faculty of Management and Economics, Universiti Pendidikan Sultan Idris, 35900 Tanjong Malim, Perak, Malaysia, Email: fadly@fpe.upsi.edu.my 
INTERNATIONAL JOURNAL OF ACADEMIC RESEARCH IN BUSINESS AND SOCIAL SCIENCES

Vol. 8, No. 10, Oct. 2018, E-ISSN: 2222-6990 ㄷ 2018 HRMARS

\section{References}

Bear, S. E., \& Hwang, A. (2017). Downsizing and the willingness to mentor. Journal of Workplace Learning, 29(2), 82-94. doi: 10.1108/JWL-05-2016-0036

Boon, C., Eckardt, R., Lepak, D. P., \& Boselie, P. (2018). Integrating strategic human capital and strategic human resource management. The International Journal of Human Resource Management, 29(1), 34-67.

Carriger, M. (2016). To downsize or not to downsize - what does the empirical evidence suggest? Journal of Strategy and Management, 9(4), 449-473. doi: 10.1108/JSMA-10-2015-0085

Carriger, M. (2017). Does size matter? The impact of the size of downsizing on financial health and market valuation. Journal of Strategy and Management, 10(3), 313-325. doi: 10.1108/JSMA-052016-0033

Cascio, W. F. (2002). Strategies for responsible restructuring. Academy of Management Executive, 16(3), 80-91.

Chhinzer, N. N., \& Currie, E. (2014). Assessing longitudinal relationships between financial performance and downsizing. Management Decision, 52(8), 1474-1490. doi: 10.1108/MD-052014-0280

Jones, E. J. (2018). A Handbook on Transformation and Transitioning Public Sector Governance: Reinventing and Repositioning Public Sector Governance for Delivering Organisational Change. Xlibris Corporation.

Kinanga, R., \& Cheruiyot, A. C. (2015). Does downsizing strategy affect the retained employees performance? Journal of Human Resources Management Research, 1(1), 1-8. doi: $10.5171 / 2015.232566$

Nyberg, A. J., Moliterno, T. P., Hale, D., \& Lepak, D. P. (2014). Resource-based perspectives on unitlevel human capital: A review and integration. Journal of Management, 40, 316-346.

Philip, C. T., \& Ting, S. C. (2013). Responsible downsizing strategy as a panacea to firm performance: The role of dynamic capabilities. International Journal of Manpower, 34(8), 1015-1028. doi: 10.1108/IJM-07-2013-0170

Vakola, M. (1999). Business process re-engineering and organisational change: evaluation of implementation strategies. Retrieve from http://usir.salford.ac.uk/14793/1/DX208914.pdf

Vatanartıran, Ö. (2015). A Discourse analysis of communicative actions of strategy practitioners on social media (Doctoral dissertation, İstanbul Bilgi Üniversitesi).

Yaacob, M. R., \& Yusoff, M. N. H. (2010). Isu pembuangan pekerja sebagai faktor tarikan kepada keusahawanan? - Kajian awalan. Prosiding Perkim, 5(2), 121-128. 